\title{
The Relationship Between Regional Value Added and Public Capital in Finland: What Do the New Panel Econometric Techniques Tell Us?
}

\author{
Pellervo Hämäläinen \\ University of Turku \\ and \\ Tuomas Malinen \\ University of Helsinki and FDPE
}

Discussion Paper No. 256

March 2009

ISSN 1795-0562

HECER - Helsinki Center of Economic Research, P.O. Box 17 (Arkadiankatu 7), FI-00014 University of Helsinki, FINLAND, Tel +358-9-191-28780, Fax +358-9-191-28781, E-mail info-hecer@helsinki.fi, Internet www.hecer.fi 


\title{
The Relationship Between Regional Value Added and Public Capital in Finland: What Do the New Panel Econometric Techniques Tell Us?*
}

\begin{abstract}
This paper applies new panel estimation techniques to the estimation of the elasticity of private production with respect to public capital in a regional setup. We use the widely applied production function approach and regional data from Finland in the period of 19752004. In contrast to many previous studies about the productivity of public capital, we focus especially on panel estimation techniques. We show that the results from commonly applied fixed effects OLS are probably biased and sensitive to change of an estimator. To get more reliable results, we use the panel DOLS and panel DSUR estimators. According to results, public capital seems to have had a positive impact on private production.
\end{abstract}

JEL Classification: C23, R11, H54.

Keywords: Production function, panel unit root tests, panel DOLS, panel DSUR

Pellervo Hämäläinen

Department of Economics

Assistentinkatu 7

FI-20014 University of Turku

FINLAND

e-mail: pellervo.hamalainen@utu.fi
Tuomas Malinen

Department of Economics

P.O. Box 17 (Arkadiankatu 7)

FI-00014 University of Helsinki

FINLAND

email: tuomas.malinen@helsinki.fi

\footnotetext{
* We would like to thank Joerg Breitung, Markku Lanne, Leena Kalliovirta, Heikki Kauppi, Tomi Kortela, Henri Nyberg and participants in the FDPE Workshop in econometrics and computational economics in Helsinki, December 2008, participants in the HECER macroeconomics and development seminar in Helsinki, November 2008, and participants in the ACE research seminar in Turku, October 2008, for comments for the earlier versions of this paper. We would also like to thank Jaakko Salmela and Juha-Pekka Konttinen from the Statistics Finland for helping us with the data.
} 


\section{Introduction}

The productivity of public investments has been in the research agenda for 20 years. After Aschauer's (1989) path-breaking article researchers using aggregate level data have generally ended up with the conclusion that the impact of public capital on the private sector's productivity is positive, but much smaller than Aschauer's original estimate.

The aims, developments and previous results of this literature are extensively discussed in literature reviews written, for example, by Romp and de Haan (2007), Strum, Kuper and de Haan (1996) and also by Ligthart and Bom (2008), who take a metaanalysis approach to sum up results from previous studies.

The direction of the research on the productivity of public capital has changed toward regional panel analyses. ${ }^{1}$ The tightest restriction in regional analyses has been, and still is, the availability of suitable capital stock data.

On the 90's most of the regional studies used data from the US states (e.g. Munnell 1990, Evans \& Karras 1994 and Holtz-Eakin 1994) with mixed results. ${ }^{2}$ More recently, regional capital stock data have been available increasingly also for European countries, which has led to an increasing extent of regional studies using European data. Positive effect of public capital on private production or TFP is identified, at least to some extent, for West Germany (Stephan 2003), Italy (Destefanis and Sena 2005), France (Cadot, Röller and Stephan 2006) and Spain (Moreno and López-Bazo 2007 and Salinas-Jimenez 2004). In regional setup, spill-over effects of public capital have also received a lot of attention (see e.g. Pereira \& Roca-Sagalés 2003).

Especially in some older studies, econometric specification does not get much attention and basic fixed effects OLS is the most commonly used estimator. More recently, there has been more discussion about econometrics and other estimation techniques have been used. However, studies that mainly focus on the econometric problems are clearly in a minority and newest panel econometric techniques have not yet been applied at all.

In this paper, we apply new methods of panel data econometrics to Finnish regional data and estimate the elasticity of private production with respect to public capital. This elasticity has been the basic measurement for the contribution of public capital on private output (e.g. Okubo 2007). Our analysis departs from previous literature in the following ways: The focus of our paper is on the new panel econometrics techniques suitable for regional setup. We are using, in addition to traditional panel unit root tests, also tests that allow for spatial dependence across regions and breaks in the tested series. In estimation, we are using panel DOLS and panel-DSUR-estimators. Panel DOLS have been used previously only in Okubo (2007). To our knowledge, panel DSUR has not been used in this branch of literature before. In addition, the Finnish regional data has not been available before and studies using data from any of the Nordic countries have been rare.

As mentioned above, Okubo (2007) is one exception by focusing on empirical problems in regional panel data analyses. Okubo shows that commonly found negative elasticity estimate for public capital changes to positive, if panel DOLS estimator is used for the regional data of Japan. Okubo argues that negative estimate is previously found,

\footnotetext{
${ }^{1}$ Problems, such as, high multicollinearity, lack of co-integration and economically unreasonable size of elasticity estimates have been common in country-specific aggregate time series analyses. In cross-country panels problems arise, for example, from different definitions of data and various economic environments among included countries. In regional setup, these problems disappear or are less severe.

${ }^{2}$ First regional productivity analysis was published already in the 70's (see Mera 1973).
} 
because of endogeneity bias, which can be corrected by using panel DOLS.

This paper shows that all unit root tests suggest that our dependent variable, value added, would be a trend-stationary process in the period tested. This strongly contradicts the results obtained in previous studies, where value added series is usually found or assumed to be a I(1)-process. We argue that this peculiar finding may result from the fact that we have both stationary and nonstationary regional specific value added series in our data. Furthermore, we will show that the results of commonly used fixed effects OLS and panel DSUR differ substantially in sub-samples. It seems, based on the evidence from the Finnish data, that fixed effects OLS produces unreliable results in a regional setup.

Although analyses have been done using Finnish data, it is likely that some problematic features of this data are common to other regional data sets and therefore our discussion about unit root testing and choosing the most suitable estimator in regional setup is much more general.

The elasticity estimate of private production with respect to public net capital stock is 0.11 in the sample of ten fastest growing regions. This implies that public capital has positively contributed to private production, at least, in the fastest growing Finnish regions.

\section{Theoretical framework}

We assume that every region has the following general form production function

$$
Y_{t}=A\left(K 2_{t}\right) \cdot F\left(L_{t}, K 1_{t}, K 2_{t}\right),
$$

where $Y$ is private output, $L$ is private labor, $K 1$ is private capital stock and $K 2$ is public capital stock of the region.

More precisely, we define $F(\bullet)$ to be Cobb-Douglas type, as it is commonly assumed

$$
F(\bullet)=L_{t}^{\beta_{1}} \cdot K 1_{t}^{\beta_{2}} \cdot K 2_{t}^{\beta_{3}},
$$

Parameter $\beta_{i}$ measures the elasticity of private output with respect input $i \in\{L, K 1, K 2\}$.

In addition, Hicks-neutral technological progress $A$ of the region is specified as follows $^{3}$

$$
A_{t}=C e^{\delta \cdot t} \cdot K 2_{t}^{\beta_{4}},
$$

where $C$ is a constant describing initial level of productivity in the region and $t$ is a linear time trend.

Combining equations (2) and (3) yields

$$
Y_{t}=C e^{\delta \cdot t} \cdot L_{t}^{\beta_{1}} \cdot K 1_{t}^{\beta_{2}} \cdot K 2_{t}^{\left(\beta_{3}+\beta_{4}\right)},
$$

which is the standard specification used in regional analyses (see e.g. Mas, Maudos, Pérez \& Uriel (1996) or Stephan (2003)). ${ }^{4}$

\footnotetext{
${ }^{3}$ Actually, in the case of Cobb-Douglas, the choice between Hicks, Harrod or Solow neutral technological progress does not matter.

${ }^{4}$ The limitations and problems of this production function approach are well-known and discussed e.g. in Romp and de Haan (2007) or Destefanis and Sena (2005). However, we are interested in estimating the elasticity of private production with respect to public capital in a robust way for the panel data from Finnish regions. Therefore, we are taking this standard framework as given, which makes our paper, in this respect, also comparable to previous researches.
} 


\section{Data and tests}

\section{Data}

The data consists of yearly observations from 77 Finnish sub-regional units in the period of 1975-2004. Private sector's regional production is measured as value-added at factor prices. Private labor consists of number of workers in each region. Regional net capital stocks are taken from Salmela (2008), who has constructed those series using the current National Account standards. Variables are measured as constant prices at 2000 and the regional division corresponds to the situation in the year $2005 .^{5}$ The variables are described in more detail in the data appendix.

We are using public net capital stock, which is broader concept than infrastructure capital. This is due to the lack of proper data of the whole infrastructure capital stock in Finnish regions. Public capital includes part of the infrastructure, but there are also other items (such as public buildings, for example) included. In the National Accounts, part of the infrastructure capital is included also in the private sector's accounts.

\section{Unit root tests}

Many previous studies have relied on to the so called traditional panel unit root tests that assume independence of cross-sections. This is a very restrictive assumption when testing includes regions within a country. In a testing setup, where different sub-regions' series of value added are tested, it is very likely that majority of the different series are correlated and/or cointegrated with each other.

The traditional panel unit root tests are usually based on the following regression:

$$
\triangle y_{i t}=\rho_{i} y_{i, t-1}+\delta_{i}+\eta_{i} t+\theta_{t}+\varepsilon_{i t}
$$

where $\delta_{i}$ are the individual constants, $\eta_{i} t$ are the individual time trends, and $\theta_{t}$ are the common time effects. Tests rely on the assumption that $E\left[\varepsilon_{i t} \varepsilon_{j s}\right]=0 \forall t, s$ and $i \neq j$, which is required for the calculation of common time effects. Thus, if the different series are correlated and/or cointegrated, the last assumption is violated. Despite of this restriction, some tests are found to be consistent under cross-sectional cointegration (Banerjee et al. 2005).

The traditional panel unit root tests used in this study are based on the regression presented in equation (5). The null hypothesis is that $H_{0}: \rho_{i}=0 \forall i$. Tests have different assumptions about the heterogeneity of the unit root process. Levin, Lin and Chu (2002) (LLC), and Breitung's (2000) tests assume that the unit root process is common to all cross-sections and Im, Pesaran, and Shin (2003) test (IPS) and Fisher type ADF and PP tests, presented by Maddala and Wu (1999), allow for an individual unit root processes. The inclusion of individual constants and time trends is optional, although Breitung's test requires that individual trends are included. The alternative hypotheses also differ between tests. Under alternative hypothesis Levin et. al test and Fisher type ADF and PP tests assume that all series are stationary, whereas Im et al. test allows some of the series to be nonstationary. Breitung's test assumes that under alternative hypothesis all cross-sections are trend-stationary.

Table 1 presents the results of five traditional panel unit root tests. ${ }^{6}$ First test in-

\footnotetext{
${ }^{5}$ The names and the locations of sub-regional units can be found from appendix

${ }^{6}$ All the tests have been done with Eviews 6. Lag lengths have been determined using Schwarts information criterion, spectral estimation has been conducted with Bartlett kernel and bandwidth has been selected using Newey-West method.
} 
cludes individual constants and the second test includes individual constants and deterministic trends.

Table 1: Traditional panel unit root tests

\begin{tabular}{lccccc}
\hline \hline variable & LLC & Breitung & IPS & ADF & PP \\
\hline value added (c) & -4.1863 & - & -0.068 & 173.81 & 178.12 \\
& $(<.0001)$ & & $(0.473)$ & $(0.109)$ & $(0.073)$ \\
value added (c\&t) & -8.717 & -6.036 & -8.139 & 303.73 & 309.41 \\
& $(<.0001)$ & $(<.0001)$ & $(<.0001)$ & $(<.0001)$ & $(<.0001)$ \\
labor (c) & -2.885 & - & 2.274 & 93.27 & 74.392 \\
& $(0.0020)$ & & $(0.989)$ & $(1.000)$ & $(1.000)$ \\
labor (c\&t) & 1.631 & -2.132 & 1.618 & 117.49 & 53.021 \\
& $(0.949)$ & $(0.017)$ & $(0.947)$ & $(0.983)$ & $(1.000)$ \\
private capital (c) & -11.814 & - & -7.479 & 328.48 & 591.72 \\
& $(<.0001)$ & & $(<.0001)$ & $(<.0001)$ & $(<.0001)$ \\
private capital (c\&t) & -7.816 & 2.124 & 0.493 & 139.64 & 356.42 \\
& $(<.0001)$ & $(0.983)$ & $(0.689)$ & $(0.755)$ & $(<.0001)$ \\
public capital (c) & -24.468 & - & -13.911 & 515.56 & 560.41 \\
& $(<.0001)$ & & $(<.0001)$ & $(<.0001)$ & $(<.0001)$ \\
public capital (c\&t) & 3.849 & 17.767 & 16.821 & 24.289 & 22.539 \\
& $(0.999)$ & $(1.000)$ & $(1.000)$ & $(1.000)$ & $(1.000)$ \\
\hline
\end{tabular}

All variables are tested in logarithms. (c) denotes that individual constants and (c\&t) that individual constants and trends have been included in the test. Probabilities of the test statistics are presented in parentheses.

One thing is clearly visible in the results of table 1 . The results of the tests crucially depend on the inclusion of individual trends. If there are no deterministic trends included in the test, they may give flawed results. This is because the inclusion of individual deterministic trend does not alter the test. It just removes a trend in the series, if there is a trend. That is why we concentrate only on the results of those tests which include both the individual constants and trends.

According to all tests the series of value added is trend-stationary. All the other variables are non-stationary according to all tests except the series of private capital which is stationary according to LLC and PP and the series of labor, which is stationary according to Breitung's test. However, it is likely that most of the tested series are correlated or even cointegrated across sub-regional units. This would violate the assumption of uncorrelated residuals among cross-sections, i.e. $E\left[\varepsilon_{i t} \varepsilon_{j s}\right]=0 \forall t, s$ and $i \neq j$. Different regions of a country are likely to be spatially dependent as they (usually) lie in the same geographical area. This would violate the assumption of independence of error processes, but the different spatially dependent statistical units need not to be statistically correlated or integrated (Baltagi et al. 2007).

To account for spatial dependence and/or correlation between the tested series we conduct Phillips and Sul's (2003) (PS) panel unit root test. Baltagi et al. (2007) found that it performed robustly in the presence of spatial dependence compared to traditional panel unit root tests. Phillips and Sul's test is based on the regression

$$
\triangle y_{i t}=\rho y_{i, t-1}+\eta_{i} t+\alpha_{i}+\delta_{i} \theta_{t}+\varepsilon_{i t},
$$

where $\alpha_{i}$ s are the individual constants, $\eta_{i} t$ are the individual time trends, $\theta_{t}$ is the common time effect whose coefficients, $\delta_{i}$, are assumed to be non-stochastic, measure 
the impact of the common time effects of series $i, \varepsilon_{i t} \sim$ i.i.d.N $\left(0, \sigma^{2}\right)$ over $t$, and $\varepsilon_{i t}$ is independent of $\varepsilon_{j s}$ and $\theta_{s}$ for all $i \neq j$ and $s, t$. Cross-sectional dependence is allowed through the common time effects which are proxied by the cross-section mean of $y_{i} t$ $\left(\bar{y}_{t}=N^{-1} \sum_{j=1}^{n} y_{j t}\right)$ and its lagged values, $\bar{y}_{t-1}, \bar{y}_{t-2}$, etc. The null hypothesis is that $H_{0}: \rho_{i}=0 \forall i$ and the alternative hypothesis is that majority of the series are stationary.

In addition to spatial dependence, the possibility of structural breaks should be taken into account in unit root tests. Many Nordic countries experienced a severe economic downturn at the beginning of the 1990s. In Finland, one of the most important factors that contributed to this rapid downturn was financial crisis that stemmed from reckless lending by banks after credit restrictions were eased in the late 1980s. In the aftermath, one of the major banks in Finland went bust and Finland as a country was driven on the verge of bankruptcy. Cause of bursting property and equity bubbles and aggressive cutbacks in lending, the downturn was very rapid (GDP growth was $+5,4 \%$ in $1989,+0,1$ in 1990 and $-6,2 \%$ in 1991 followed by two years of contraction). This structural shift is clearly visible in the Finnish GDP series. It also likely that in the span of 30 years almost all countries in the world have experienced a recession.

To account for possible structural breaks in the tested series we use Im et al. (2005) (ILT) panel unit root test that allows for structural shifts in the tested series. Im et al. test assumes the following data generating process:

$$
\begin{array}{r}
y_{i t}=z_{i t}+x_{i t} \\
z_{i t}=\gamma_{1 i}+\gamma_{2 i} t+\delta_{i} D_{i t}, \\
x_{i t}=\phi_{i} x_{i, t-1}+\varepsilon_{i t}
\end{array}
$$

where

$$
D_{i t}=\left\{\begin{array}{ll}
0 & t \leq T_{B, i} \\
1 & t \geq T_{B, i}+1
\end{array},\right.
$$

where $T_{B, i}$ is the time period of structural shift in the $i$ th series and $\varepsilon_{i t} \sim$ i.i.d.N $\left(0, \sigma^{2}\right)$. After rearranging, equation (7) becomes

$$
\triangle y_{i t}=\beta_{i} y_{i, t-1}-\beta_{i} \gamma_{1 i}+\left[1-\left(\beta_{i}+1\right)(t-1)\right] \gamma_{2 i}+\varepsilon_{i t},
$$

where $\beta_{i}=-\left(1-\phi_{i}\right)$. The null hypothesis is that $H_{0}: \beta_{i}=0 \forall i$ and the alternative hypothesis is that $H_{1}: \beta_{i}<0$ for some $i$.

We run two versions of each test. For Phillips and Sul's (2003) test we first run a test including only individual constants and then a test that includes both individual constants and deterministic trends. First Im et al. (2005) test allows for no breaks in the tested series and the second one allows for one common break in the series.

Im et al. (2005) test estimates the time of the break in the different series and then uses a common time dummy to control for the break. Im et al. test is unbiased only when there is a break in the series. That's why we only report the results of ILT test with break when there seems to be a one structural break in the series. In the individual time series of value added, there is a clear break point visible in the value added series in the year 1990. This is also the same year that the ILT test estimates as a break point. Labor series seems to have two break points: In the late 1970s and around 1990. ILT estimates the break point to be in the year 2000, which is clearly off. In the private capital series, there is a clear break visible in 1990-1991. ILT estimates that break point is in 1991. In the case of public capital series, there is no break visible. Table 2 presents the results of Im et al. and Phillips and Sul's (2003) tests. ${ }^{7}$

\footnotetext{
${ }^{7}$ Tests have been conducted with Gauss. Gauss code for ILT and PS tests were provided by Im et. al
} 
Results of Phillips and Sul's (2003) test support the findings of traditional tests, i.e. the inclusion of individual trends in the test alters the results significantly. On the other hand, according to Im et al. (2005) test, value added and private capital series are stationary, if we allow for one break point in the tested series.

Thus, both tests seem to enforce the result of the traditional tests, i.e. that the value added series would be a stationary $A R(p)$ process in the tested period. However, all of these tests have their reservations. Traditional panel unit root tests and ILT test assume cross-sectional independence. Phillips and Sul's (2003) test allows for cross-sectional correlation, but may be inconsistent in the presence of cross-sectional cointegration. If tested series are cross-sectionally cointegrated, the common trends present in the data may be identified as common factors in equation (6) and removed from the analysis (Breitung \& Pesaran 2005). In this case, if the remaining idiosyncratic component is stationary, the test has tendency to present the time series as stationary when panel units are actually nonstationary. ${ }^{8}$

The trend-stationarity of value added series may also result from large number of stationary value added series in the panel. The economic reason for this finding could be the highly diverse economic development in the Finnish sub-regional units. In Finland, especially, population is concentrated on few rapidly growing areas, and most of the value added growth comes from these few heavily populated areas. Thus, we may have several depressing sub-regions, whose value added growth is slightly upward slopping or stays more or less constant. In these sub-regions, the value added series may be more like a trend-stationary series, whereas few heavily populated rapidly developing regions have clearly more dynamic, integrated value added series growth.

So, the somewhat surprising result of trend-stationarity of the regional value added series could result from a strong cross-sectional cointegration and/or from large number of stationary series in the panel. Series could also have processes local to unit root, which could bias the results of our panel unit root tests (Phillips 1987). For these reasons we have also run Pedroni's (2004) panel cointegration tests on our variables.

(2005) and Phillips and Sul's (2003).

${ }^{8}$ Panel unit root tests that allow for different forms of cross-sectional dependence, including crosssectional cointegration, have been developed, but, to our knowledge, all these tests require panels with large dimensions of $T$ and $n$ (eg. Bai \& Ng 2004). Our panel has a relatively large cross-sectional dimension (76), but the time dimension is relatively small ( 29 observations).

Table 2: Panel unit root tests allowing for cross-sectional dependence/structural shifts

\begin{tabular}{lcccc}
\hline \hline variable & ILT (no break) & ILT (1 break) & PS (c) & PS (c\&t) \\
\hline $\log$ (value added) & -8.384 & -8.718 & 100.98 & 319.49 \\
& $(<.0001)$ & $(<.0001)$ & $(0.999)$ & $(<.0001)$ \\
$\log ($ labor $)$ & -5.476 & - & 70.450 & 223.44 \\
& $(<.0001)$ & & $(1.000)$ & $(<.0001)$ \\
$\log$ (private capital) & 0.158 & -33.990 & 151.43 & 266.99 \\
& $(0.934)$ & $(<.0001)$ & $(0.452)$ & $(<.0001)$ \\
$\log$ (public capital) & -0.771 & - & 199.79 & 97.301 \\
& $(0.656)$ & & $(0.004)$ & $(0.999)$ \\
\hline
\end{tabular}

$P$-values of the test statistics are presented in parentheses. The values presented without brackets denotes the value of $z$-statistics. 
Table 3 summarizes the results of Pedroni’s 11 panel cointegration test statistics. ${ }^{9}$

Table 3: Summary of the results of Pedroni's panel cointegration test statistics

\begin{tabular}{lc}
\hline \hline Dependent variable: $\log ($ value added $)$ & $\begin{array}{c}\text { Number of test statistics } \\
\text { that reject } H_{0} \text { at } 5 \% \text { level }\end{array}$ \\
\hline $\log$ (labor) & $10 / 11$ \\
$\log$ (private capital) & $9 / 11$ \\
$\log$ (public capital) & $10 / 11$ \\
all variables & $10 / 11$ \\
\hline
\end{tabular}

Null hypothesis is that there is no cointegration between the variables. Lag length were determined with Schwarz information criterion. Spectral estimation was done with Bartlett method and bandwidth was selected with Newey-West method.

As is visible in table 3, majority of the Pedroni's (2004) test statistics support the hypothesis of cointegration between value added and all explanatory variables. But, as Pedroni's (2004) test is residual based, it requires that the dependent variable (value added) is a nonstationary process. As almost all of our panel unit root tests conclude that the value added series is trend-stationary process, the results of Pedroni's panel cointegration tests have to be taken cautiously. Nonetheless, we are left with one choice. Try to take the possibility of cointegration between the value added series and some or all series of explanatory variables into account in estimation. Assuming a $I(0)$ dependent variable with $I(1)$ regressors would also create problems in estimation cause such a setup could result to spurious regressions (Stewart 2007).

\section{Estimation}

Some previous studies have used standard panel estimators on data that is found or assumed to include cointegrating relations. Unfortunately, many standard panel estimators are not consistent or asymptotically unbiased in panel cointegrated data. For example, GMM estimator is inconsistent when the dependent variable is not stationary. OLS is also not asymptotically unbiased, if panel includes cointegrating relations between the dependent and explanatory variables (Kao \& Chiang 2000). We account for the possible cointegration in the panel by using the panel dynamic OLS estimator, which is a consistent estimator in cointegrated panel data, and that also accounts for possible endogeneity present in the model. However, panel DOLS does not fully account for the possible correlation and/or cointegration between statistical units of the panel. That is why we also use the panel dynamic seemingly unrelated regressors estimator, which accounts for this correlation/cointegration.

To make a comparison, we first estimate our production function with traditional panel estimators. We estimate a model:

$$
\begin{array}{r}
\log (\text { valueadded })_{i t}=\alpha+\beta_{1} \log (\text { labor })_{i t}+\beta_{2} \log (\text { publiccapital })_{i t} \\
+\beta_{3} \log (\text { privatecapital })_{i t}+\text { dummy }_{(1991-1993)} \\
+ \text { trend }+\varepsilon_{i t} .
\end{array}
$$

On $\varepsilon_{i t}$ we assume following error structure:

$$
\varepsilon_{i t}=\mu_{i}+v_{i t}
$$

\footnotetext{
${ }^{9}$ Tests were conducted with Eviews 6. Detailed results are available upon request.
} 
i.e. we assume that error process is one-way. Here, the disturbance term $v_{i t}$ is assumed to be i.i.d.

We also include a dummy variable to account for the severe economic downturn in 1991-1993. As a reference point the equation (9) is estimated also only for the private sector and without cross-section specific constants. Table 4 reports the results. In a way, second and third equation serve as a benchmark cases estimated in the most of previous studies. In addition, we also include a variable that combines public capital in each region to public capital in neighboring regions. This variable is supposed to take spill-over effects into account and it is constructed similarly as in Mas et al. (1996).

Table 4: OLS production function estimates

\begin{tabular}{|c|c|c|c|c|}
\hline \multicolumn{5}{|c|}{ Dependent variable: $\log ($ value added $)$} \\
\hline variable & Pooled & One-way FE & One-way FE & One-way FE \\
\hline constant & $\begin{array}{l}-3.489 * * * * \\
(0.1760)\end{array}$ & - & - & - \\
\hline $\log$ (labor) & $\begin{array}{l}0.5413 * * * * \\
(0.0560)\end{array}$ & $\begin{array}{l}0.7529 * * * \\
(0.0520)\end{array}$ & $\begin{array}{l}0.7675 * * * \\
(0.0519)\end{array}$ & $\begin{array}{l}0.7800 * * * \\
(0.0473)\end{array}$ \\
\hline $\log ($ private capital) & $\begin{array}{l}0.5721 * * * * \\
(0.0626)\end{array}$ & $\begin{array}{l}0.2789 * * * \\
(0.0642)\end{array}$ & $\begin{array}{l}0.2355^{* * *} * \\
(0.0665)\end{array}$ & $\begin{array}{l}0.2192 * * \\
(0.0751)\end{array}$ \\
\hline $\log ($ public capital) & $\begin{array}{l}-0.0144 \\
(0.0287)\end{array}$ & - & $\begin{array}{l}0.0924 * \\
(0.0406)\end{array}$ & - \\
\hline $\log ($ combined $)$ & - & - & - & $\begin{array}{l}0.1533 * * \\
(0.0581)\end{array}$ \\
\hline dummy & $-0.0686 * * * *$ & $-0.025 * *$ & $-0.031 * * *$ & $-0.035^{* * *}$ \\
\hline$(1991-1993)$ & $(0.0112)$ & $(0.009)$ & $(0.009)$ & $(0.008)$ \\
\hline trend & $\begin{array}{l}0.0189 * * * * \\
(0.0018)\end{array}$ & $\begin{array}{l}0.0259 * * * \\
(0.0016)\end{array}$ & $\begin{array}{l}0.0249 * * * \\
(0.0016)\end{array}$ & $\begin{array}{l}0.0242 \\
(0.0016)\end{array}$ \\
\hline $\begin{array}{l}\text { joint } \\
\text { significance }\end{array}$ & - & $\begin{array}{l}41.01 \\
(<0.0001)\end{array}$ & $\begin{array}{l}41.59 \\
(<0.0001)\end{array}$ & $\begin{array}{l}41.59 \\
(<0.0001)\end{array}$ \\
\hline sub-regions & 76 & 76 & 76 & 76 \\
\hline years & 29 & 29 & 29 & 29 \\
\hline observations & 2204 & 2204 & 2204 & 2204 \\
\hline
\end{tabular}

The value of the $F$-test for the joint significance of sub-region dummy coefficient indicates that sub-regions dummies are jointly significant. Thus, normal cross-sectional or pooled estimation would suffer from omitted-variables bias.

Basic production function estimates (table 4) seem economically reasonable in sign and size. Estimates for private inputs are highly statistically significant also when both capital stocks are included. Public capital gets an estimate of 0.09 , which is well in line with previous results from regional studies done for European countries. The combined variable is statistically significant and the estimate is greater than the estimate for public capital solely. This suggests that there are some spill-over effects present. As results from joint significance test already point out, fixed effects specification is necessary in regional setup. In table 4 White period method is used to correct standard errors for serial correlation. Overall, results look quite similar to previous studies. 
The general problem in production function estimation is the possible endogeneity of regressors. To account for this, and the possible cointegration between dependent and some or all explanatory variables, we use the panel dynamic OLS estimator developed by Mark and Sul (2003). Mark and Sul's estimator accounts for cross-sectional dependence by introducing a common time effect. ${ }^{10}$

Mark and Sul's (2003) estimator assumes that observations on each individual $i$ obey the following triangular representation

$$
y_{i t}=\alpha_{i}+\lambda_{i} t+\theta_{t}+\gamma x_{i t}+u_{i t},
$$

where $\left(1,-\gamma^{\prime}\right)$ is a cointegrating vector between $y_{i t}$ and $x_{i t}$, which is identical across individuals, $\alpha_{i}$ is an individual-specific effect, $\lambda_{i} t$ is a individual-specific linear trend, $\theta_{t}$ is a common time-specific factor, and $u_{i t}$ is a idionsyncratic error that is independent across $i$, but possibly dependent across $t$. The model (11) allows for a limited form of cross-sectional correlation where the equilibrium error for each individual is driven in part by $\theta_{t}$.

Panel DOLS eliminates the possible endogeneity between explanatory variables and dependent variable by assuming that $u_{i t}$ is correlated at most with $p_{i}$ leads and lags of $\triangle x_{i t}$. This endogeneity can be controlled for by projecting $u_{i t}$ onto these $p_{i}$ leads and lags:

$$
u_{i t}=\sum_{s=-p_{i}}^{p_{i}} \delta_{i, s}^{\prime} \triangle x_{i, t-s}+u_{i t} *=\delta_{i}^{\prime} z_{i t}+u_{i t} *
$$

The projection error $u_{i t} *$ is orthogonal to all leads and lags of $\triangle x_{i t}$ and the estimated equation becomes

$$
y_{i t}=\alpha_{i}+\lambda_{i t}+\theta_{t}+\gamma^{\prime} x_{i t}+\delta_{i}^{\prime} z_{i t}+u_{i t} *,
$$

where $\delta_{i}^{\prime} z_{i t}$ is a vector of projection dimensions. The consistent estimation of (13) is based on sequential limits, i.e. as $T \rightarrow \infty$ then $n \rightarrow \infty$.

Previously, panel DOLS has been used in regional analysis only by Okubo (2007), who argued that panel DOLS eliminates the endogeneity bias in nonstationary and cointegrated panels. In the case of Japan, Okubo (2007) showed that the results of traditional LSDV-estimator do not hold, if the equation is estimated with panel DOLS. When panel DOLS was used, the negative elasticity estimate for public capital, a result generally found in previous studies, changed to positive.

Table 5 presents the results of dynamic OLS fixed-effects estimations of equation (9). ${ }^{11}$ DOLS estimation uses leads and lags of 1 to account for possible correlation between equilibrium error and $\triangle x_{j t}, j=1, \ldots, n$. DOLS estimator uses Andrew and Mohanan's pre-whitening method to account for possible autocorrelation. DOLS estimations include individual constants and individual trends, but their values are not presented in table 5.

DOLS estimates suggest that the coefficient of public capital is negative and insignificant if possible spillover effects are not taken into account. The combined variable gets positive, but still statistically insignificant estimate. Elasticity estimates for

\footnotetext{
${ }^{10}$ Wagner and Hlouskova (2007) have compared the performance of different estimators for panel cointegrated data. They found that DOLS system estimator (panel DOLS) performs robustly in the presence of cross-unit correlation or cointegration compared to several other estimators developed for panel cointegrated data. The tested estimators included FM-OLS presented by Phillips and Moon (1999), DOLS presented by Kao and Chiang (2000) and Mark and Sul (2003), one-step VAR, and two-step VAR presented by Breitung (2005)

${ }^{11}$ Estimation is conducted with Gauss. Gauss code has been provided by Mark and Sul (2003).
} 
Table 5: Dynamic OLS production function estimates

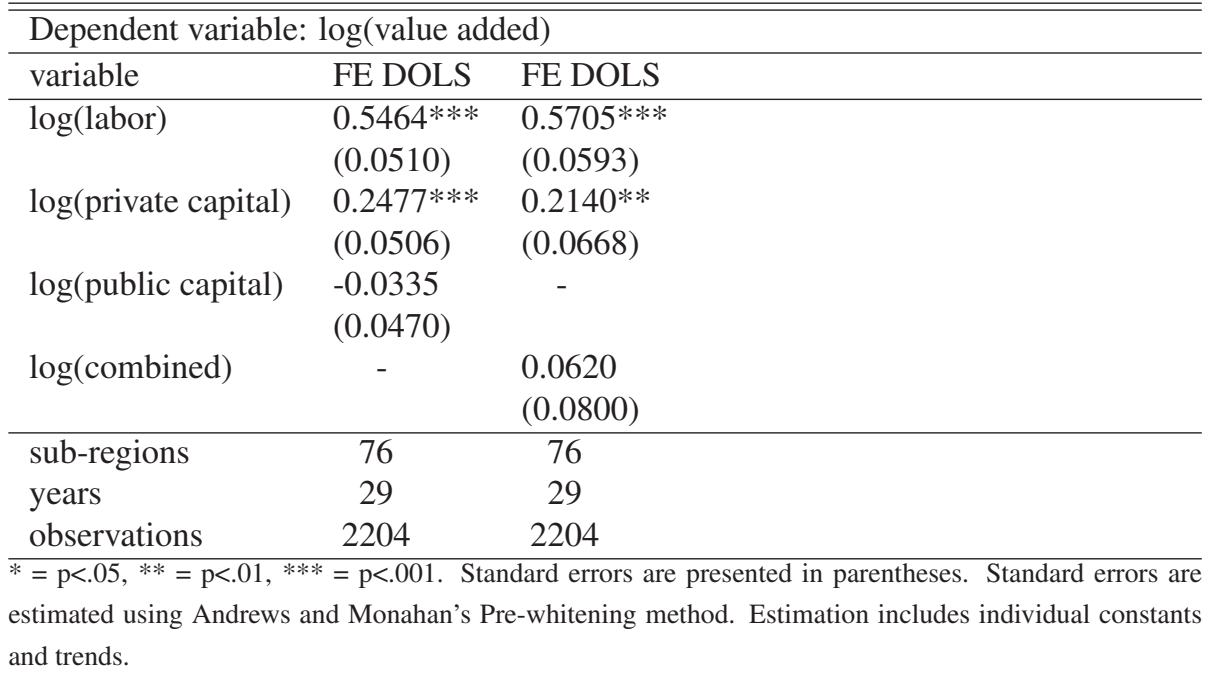

private inputs remain statistically significant and reasonable in size. Nevertheless, the results of panel DOLS estimation on the effect of public capital differ substantially on OLS estimations. This implies that some or all of the explanatory variables appearing in the model may be endogenous and/or there are cointegrating relations between the dependent variable and some or all explanatory variables.

However, the results of panel DOLS estimation may have been affected by endogeneity if leads and lags of 1 have not been enough to remove the correlation between equilibrium error and first differenced explanatory variables. ${ }^{12}$ It is also possible that the common time-effect included in panel DOLS estimation has not captured all the cross-sectional correlation present in the data. This is a problem especially, if there remains correlation between equilibrium error, $u_{i t}$, and leads and lags of other crosssections $\triangle x_{j t}, j \neq i$. In this case the panel DOLS exhibits the same form of second order asymptotic bias as pooled OLS (Mark \& Sul 2003). To account for this, panel DSUR estimator is used, which controls for the endogeneity between equilibrium errors and cross-equations (Mark et al. 2005). Panel DSUR estimates a long-run covariance matrix that is used in the estimation. This actually makes panel DSUR more efficient the more the cross-sections are correlated across the panel. Endogeneity is controlled by including leads and lags of first differenced explanatory variables into the regression as in panel DOLS estimator.

The drawback of panel DSUR is that estimation of the long-run covariance matrix requires large time series dimension compared to cross-sectional dimension (Mark et al. 2005). In our case, the panel can include up to 10 cross-sections. ${ }^{13}$ As mentioned in the previous section, some of the Finnish sub-regions have grown progressively whilst some have stagnated. It is thus reasonable to analyze these two categories in our restricted estimation. To do this, we select 10 sub-regions that have increased their value added the most and 10 sub-regions that have increased their value added the least be-

\footnotetext{
${ }^{12}$ We also estimate our model using leads and lags of 2 using only three explanatory variables, private and public capital and labor, and leads and lags of 3 using only public capital as explanatory variable. There were no major changes in the values or standard errors of parameter estimates of public capital.

${ }^{13}$ If the cross-sectional size is increased beyond this point, panel DSUR fails to converge.
} 
tween 1976 and 2004. Differences in the growth rate between these two samples are quite large. 10 fastest growing sub-regions of Finland have grown with the annual rate of $3,8 \%$ in average while the slowest growing sub-regions have grown with the annual rate of $0,55 \%$ in average.

According to Levin et al. (2002), Im at al. (2003), ADF, and PP panel unit root tests, the value added series is $I(1)$ in the sample of 10 fastest growing sub-regions. In the sample of 10 slowest growing sub-regions, all the traditional tests presented previously find the value added series to be $I(0)$. This implies that there would be some non-stationary and some stationary series of valued added in the panel. Table 6 presents the summary of the results of Pedroni's (2004) panel cointegration test for 10 fastest growing sub-regions. ${ }^{14}$

Table 6: Summary of the results of Pedroni's panel cointegration test statistics for 10 sub-regions that have grown the fastest

\begin{tabular}{lc}
\hline \hline Dependent variable: $\log ($ value added $)$ & $\begin{array}{c}\text { Number of test statistics } \\
\text { that reject } H_{0} \text { at } 5 \% \text { level }\end{array}$ \\
\hline $\log ($ labor $)$ & $10 / 11$ \\
$\log$ (private capital) & $3 / 11$ \\
$\log$ (public capital) & $8 / 11$ \\
all variables & $8 / 11$ \\
\hline
\end{tabular}

Null hypothesis is that there is no cointegration between the variables. Lag length were determined with Schwarz information criterion. Spectral estimation was done with Bartlett method and bandwidth was selected with Newey-West method.

According to the results presented in table 6, the series of value added and labor, and value added and public capital seem to be cointegrated. Only 3 out of 11 Pedroni's (2004) test statistics find the value added and private capital to be cointegrated. However, the results of table 6 needs to be interpreted cautiously because of size distortions in Pedroni's test with small dimensions on $n$ and $T$ (Banerjee et al. 2005).

Table 7 presents the results of panel DSUR estimation of equation (9). ${ }^{15}$ Panel DSUR includes common time effects, individual constants, and individual trends. A parametric correction is used to account for possible autocorrelation. As a reference we have also estimated a simple random sample drawn from the remaining 56 sub-regions.

All elasticity estimates estimated by panel dynamic SUR are highly statistically significant. Public capital gets an elasticity estimate of 0.11 in the sample of 10 fastest growing regions. Labor gets quite high elasticity estimate compared to the results of panel DOLS. However, the size of these estimates is still reasonable. Results suggest that public capital has had a positive impact on private output.

The results for the sample of 10 fastest growing regions are the most reliable from the panel econometric viewpoint. In this sample, all variables are nonstationary and cointegrated according to our tests. Thus, the possible problem of spurious regression, which may have been present in the previous estimations done with the whole data, has disappeared. In addition, panel dynamic SUR is not only consistent when regions are correlated or cointegrated with each other, but is also more efficient when this is the case.

\footnotetext{
${ }^{14}$ Tests were done with Eviews 6.

${ }^{15}$ Estimation is conducted with Gauss. Gauss code was provided by Mark et al. (2005)
} 
Table 8: OLS production function estimates II

\begin{tabular}{|c|c|c|c|}
\hline \multicolumn{4}{|c|}{ Dependent variable: $\log ($ value added $)$} \\
\hline variable & 10 fastest & 10 slowest & 10 "normal" \\
\hline \multirow[t]{2}{*}{$\log$ (labor) } & $0.6550 * * *$ & $0.7105 * * *$ & $0.5741 * * *$ \\
\hline & $(0.0786)$ & $(0.0525)$ & $(0.0408)$ \\
\hline \multirow[t]{2}{*}{$\log ($ private capital $)$} & 0.1531 & -0.0557 & $0.4134 * * *$ \\
\hline & $(0.1683)$ & $(0.0395)$ & $(0.0532)$ \\
\hline \multirow[t]{2}{*}{$\log ($ public capital) } & 0.0392 & $0.5477 * * *$ & -0.0436 \\
\hline & $(0.2158)$ & $(0.0913)$ & $(0.0397)$ \\
\hline dummy & $-0.0832 * *$ & $-0.0297 * *$ & $-0.0462 * *$ \\
\hline$(1991-1993)$ & $(0.030)$ & $(0.0099)$ & $(0.0147)$ \\
\hline \multirow[t]{2}{*}{ trend } & $0.0367 * * *$ & $0.0147 * * *$ & $0.0194 * * *$ \\
\hline & $(0.0056)$ & $(0.0019)$ & $(0.0012)$ \\
\hline sub-regions & 10 & 10 & 10 \\
\hline years & 29 & 29 & 29 \\
\hline observations & 290 & 290 & 290 \\
\hline \multicolumn{4}{|c|}{$\begin{array}{l}=\mathrm{p}<.05, * *=\mathrm{p}<.01, * * *=\mathrm{p}<.001 . \text { Standard errors are presented in parentheses. Standard errors are cor- } \\
\text { ected for serial correlation using White period method. Estimations is with fixed-effects. } 10 \text { fastest includes } \\
\text { ub-regions whose value added series have grown the fastest between 1976-2004. } 10 \text { slowest includes sub- } \\
\text { egions whose value added series have grown the slowest between 1976-2004. } 10 \text { normal includes a simple } \\
\text { andom sample of } 10 \text { sub-regions on the remaining } 56 \text { sub-regions. }\end{array}$} \\
\hline
\end{tabular}

spatial dependencies and structural breaks. Second, we searched for the most reliable panel estimator to estimate the elasticity of private production with respect to public capital. The problem with fixed effects OLS, that is traditionally used in regional panel studies, is that it is not asymptotically unbiased in panel cointegrated data. We also argue that regional panels are likely to suffer from strong cross-sectional correlation, which causes bias in fixed effects OLS estimation. We ended up with panel dynamic SUR-estimator, which controls for endogeneity and is asymptotically unbiased in cointegrated panel data and efficient when the cross-sections of the panel are correlated.

Panel unit root tests suggest that our dependent variable would be a trend-stationary process, which is quite unexpected finding. Our results imply that the panel of Finnish sub-regions includes both stationary and nonstationary series of value added. In panel unit root testing, this may result to flawed conclusion that the whole panel would be stationary.

Stationary series of value-added in the panel are a problem for estimation, because regressing values of stationary dependent variable against $I(1)$ variables may lead to spurious regressions. In the sample of 10 fastest growing regions, all series seemed to have unit roots and they also seemed to be cointegrated. For this sub-sample estimation results with panel DSUR are econometrically reliable.

The elasticity estimate of 0.11 for public capital obtained from panel DSUR estimation implies that public capital has positively contributed to private production in 10 of the fastest growing regions of Finland during the sample period of 1975-2004. The result is well in line with the quite common agreement among researchers that public capital has a positive effect on private output.

Although, it may seem that the results with Finnish data just confirm the previous findings from other European countries, we want to emphasize that our results are obtained using different estimation technique. We show that the results may differ sub- 
stantially, if the panel dynamic SUR estimator is used instead of fixed effects OLS. In the Finnish case, the conclusions would be totally different if we would have used fixed effects OLS. Thus, our results challenge the suitability of basic FE-OLS estimator in estimating the productivity of public capital from regional data. Our results imply that fixed effects OLS may lead to false conclusions and may be useful only as a reference point for other estimators. Instead, panel DSUR could become main estimator of regional panels in future. 


\section{References}

Aschauer, David A. (1989): Is Public Expenditure Productive? Journal of Monetary Economics, 23, 177-200.

Bai, Jushan \& NG, SEREnA (2004). A panic attack on unit roots and cointegration. Econometrica, 4, 1127-1177.

Baltagi, Badi H., Bresson, Georges \& Pirotte, Alain (2007): Panel unit root tests and spatial dependence. Journal of Applied Econometrics, 22, 339-360.

Banerjee, Anindya, Marcellino, Massimiliano \& Osbat, Chiara (2005): Testing for PPP: Should we use panel methods? Empirical Economics, 30, 77-91.

BREITUNG, JoERG (2000): The local power of some unit root tests for panel data. Advances in Econometrics, 15, 161-177.

Breitung, Joerg \& Pesaran, Hashem (2005). Unit roots and cointegration in panels. CESifo Working paper no. 1565.

CAdot, Olivier, Röller, LARS-Hendrik \& Stephan, Andreas (2006): Contribution to productivity or pork barrel? The two faces of infrastructure investment. Journal of Public Economics, 90, 1133-1153.

Destefanis, Sergio \& Sena, Vania (2005): Public Capital and Total Factor Productivity: New Evidence from the Italian Regions 1970-98. Regional Studies, 39(5), 603-617.

Evans, Paul \& Karras, Georgios (1994): Are Government Activities Productive? Evidence from a Panel of U.S. States. The Review of Economics and Statistics, 76(1), 1-11.

Holtz-Eakin, Douglas (1994): Public-Sector Capital and the Productivity Puzzle. The Review of Economics and Statistics, 76(1), 12-21.

Im, Kyung-So, Pesaran, Hashem \& Shin, Yongcheol (2003): Testing for units roots in heterogenous panels. Journal of Econometrics, 115, 53-74.

KAO, CHIHWA \& CHIANG, MIN-HSIEN (2000): On the estimation and inference of a cointegrated regression in panel data. Advances in Econometrics, 15, 179-222.

KAO, CHIHWA (1999): Spurious regressions and and residual-based tests for cointegration in panel data. Journal of Econometrics, 90, 1-44.

LeVin, ANDrew, Lin, ChiEN-Fu \& CHU, JAMEs ChiA-SAng (2002): Unit root test in panel data: Asymptotic and finite sample properties. Journal of Econometrics, 130, 236-252.

Ligthart, Jenny E. \& Bom, Pedro R.D. (2008): How Productive is Public Capital? A Meta Analysis. CESIFO Working Paper No 2206, Category 5; January 2008

Maddala, G.S. \& WU, ShaOWEN (1999). A comparative study of unit root tests with panel data and a new simple test. Oxford Bulletin of Economics and statistics, special issue, pp. 631-52.

Mas, Matilde, Maudos, Joaquín, Pérez, Francisco \& Uriel, Ezequiel (1996): Infrastructures and Productivity in the Spanish Regions, Regional Studies, 30(7), 641-649.

Mark, Nelson, Masao, Ogaki and Dongguy, Sul (2005): Dynamic seemingly unrelated cointegrating regressions. Review of Economic Studies, 797-819. 
McCoskey, SuzAnne \& Kao, Chihwas (1998): A residual based test of the null of no cointegration.Econometric Reviews, 17, 57-84.

Mera, Koichi (1973): Regional Production Functions and Social Overhead Capital: An Analysis of the Japanese Case. Regional and Urban Economics, 3(2), 157-186.

Munnell, Alicia H. (1990): How Does Public Infrastructure Affect Regional Economic Performance? In Alicia Munnell (ed.) Is There a Shortfall in Public Capital Investment?, Conference Series No. 34, 69-103, Federal Reserve Bank of Boston.

Moreno, Rosina \& López-BAzo, EnRiQue (2007): Returns to Local and Transport Infrastructure under Regional Spillovers. International Regional Science Review, 30(1), 47-71.

OKUBO, MASAKATSU (2007): Public capital and productivity: a nonstationary panel analysis. Applied Econometric Letters, 15(2), 95-99.

Pedroni, Peter (2004). Panel cointegration: Asymptotic and finite sample properties of pooled time series tests with an application to PPP hypothesis. Econometric Theory, 20, pp. 597-625.

Pereira, Alfredo M. \& RocA-Sagalés, Oriol (2003): Spill-over Effects of Public Capital Formation: Evidence from the Spanish Regions. Journal of Urban Economics, Vol 53, 238-256.

Phillips, PETER C. B. (1987). Towards unified asymptotic theory for autoregression. Biometrika, 74, 535-47.

Phillips, Peter C. B. and Moon, Hyungsik R. (1999): Linear regression limit theory for nonstationary panel data. Econometrica, 67(5), pp. 1057-11.

Phillips, Peter C.B. \& Sul, Donggyu (2003): Dynamic Panel Estimation and Homogeneity Testing under Cross Section Dependence. Econometrics Journal, 6, 217-259.

ROMP, WARD \& DE HAAN, JAKOB (2007): Public Capital and Economic Growth: A Critical Survey. Perspektiven der Wirtschaftspolitik 2007, Vol 8 (Special Issue), $6-52$.

SAlinAS-Jimenez, DEL MAR, M. (2004): Public infrastructure and private productivity in the Spanish regions. Journal of Policy Modeling, 26, 47-64.

SALMELA, JAAKKO (2008): Teollisuuden alueelliset pääomakannat Suomessa 19752004. [Regional capital stocks for Finnish industry 1975-2004] Pro gradu -työ. Taloustieteiden tiedekunta, Jyväskylän yliopisto (Master Thesis, Faculty of Economics, University of Jyväskylä).

Statistics Finland (2005): Municipalities and Regional Division Based on Municipalities 2005. Handbooks 28.

STEPHAN, ANDREAS (2003): Assessing the contribution of public capital to private production: Evidence from German manufacturing sector. International Review of Applied Economics, 17(4), 399-417.

STEWART, CHRIS (2007): Spurious correlation of $I(1)$ regressors in models with and $I(0)$ dependent variable: Asymptotic results. London Metropolitan University discussion paper.

Strum, Jan-Egbert, Kuper, Gerard H. \& De HaAn, JAKob (1996): Modelling government investment and economic growth on a macro level: a review. CCSO Working Paper Series No. 29. 
UIMONEN, SAKARI (2007): Suomen infrastruktuuripääoma: Tiet [Finnish infrastructure capital: Roads]VATT-keskustelualoitteita, 436 (Discussion Papers, 436. Government Institute for Economic Research).

UIMONEN, SAKARI (2008): Suomen infrastruktuuripääoma: Rautatiet [Finnish infrastructure capital: Railroads] VATT-keskustelualoitteita, 439 (Discussion Papers, 439. Government Institute for Economic Research).

WAGNER, MARTIN and HLOUSKOVA, JAROSLAV (2007). The performance of panel cointegration methods: Results from a large scale simulation study. Institute for Advanced Studies, working paper.

http://www.ihs.ac.at/publications/eco/es-210.pdf 


\section{Data Appendix}

General notices: The data consists of yearly observations from 77 Finnish subregional units (seutukunta in finnish) ${ }^{16}$ in the period of 1975-2004. ${ }^{17}$

Variables are measured as constant prices at 2000 and the regional division corresponds to the situation in the year 2005 (see appendix). All industries are included.

All three capital stock series are measured at the end of the year. Therefore, for the year $t$ we have used $t-1$ values of the capital stocks in the estimated production functions. Due to this correction our sample in estimation is 1976-2004.

Regional output $Y$ : Private sector's regional production is measured as value-added at factor prices. The data is taken from official statistics complied by Statistics Finland after wide revision of National Account statistics finalized in the spring 2006.

Labor $L$ : Private labor consists of number of workers. The number of hours would be better variable, but it is not available at sub-regional level prior to 1995 . The data is taken from official statistics complied by Statistics Finland.

Private capital $K 1 \quad$ : Private capital is measured as private net capital stock. Net capital stocks are taken from Salmela (2008) and they are constructed using the current National Account standards.

Public capital $K 2$ : Public capital is measured as public net capital stock, which includes both central and local governments capital stocks. Net capital stocks are taken from Salmela (2008) and they are constructed using the current National Account standards. Public capital stock is used instead of some infrastructure capital measurement. The use of the whole public capital stock can be justified by the restrictions in the availability of more proper data. Recently, there have been been attempts also in Finland to construct variables for infrastructure capital (see Uimonen 2007,2008). Until now, this is done only for roads and railroads.

OECD's current recommendation considering the productivity studies is to use effective capital, which is a flow variable measured as a volume index of serviced provided by capital. These kind of variables are available in official statistics only in three countries (the United States, Canada and Australia).

Combined public capital and spill-over This variable is constructed for region $i$ by adding up public capital in region $i$ and public capital in neighboring regions. Neighbor region is defined to have a common boarder. However, Alland's three sub-regional units are assumed to be neighbors only to each other not to regions located in the coast, which they have common (sea) boarder.

More detailed description of the data is available upon request.

\footnotetext{
${ }^{16}$ Sub-regional units do not enter in the NUTS (Nomenclature des Unités Territoriales Statistiques) classification, which became effective in 2003 as a European Union's regulation. They are one step lower than the NUTS level 3, which would be regions in the Finnish case.

${ }^{17}$ However, Porvoo is excluded due to data problems. For instance, value added drops $75 \%$ from 1985 to 1986. Actually, this is not a data error. The development of petrochemical industry in Porvoo has been highly volatile and thus the use of the series in economic analysis is not meningful.
} 


\section{Appendix: Sub regional units}

Finnish sub-regional units in 2005. Source: Statistics Finland (2005).

\begin{tabular}{|c|c|c|c|c|c|}
\hline 011 & Helsinki & 093 & Imatra & 152 & Vaasa \\
\hline 012 & Lohja & 101 & Mikkeli & 153 & Sydösterbottens region \\
\hline 013 & Tammisaari & 102 & Juva & 154 & Jakobstadsregionen \\
\hline 021 & Turunmaa & 103 & Savonlinna & 161 & Kaustinen \\
\hline 022 & Salo & 105 & Pieksämaäki & 162 & Kokkola \\
\hline 023 & Turku & 111 & Ylä-Savo & 171 & Oulu \\
\hline 024 & Vakka-Suomi & 112 & Kuopio & 173 & Oulunkaari \\
\hline 025 & Loimaa & 113 & Koillis-Savo & 174 & Raahe \\
\hline 041 & Rauma & 114 & Varkaus & 175 & Siikalatva \\
\hline 043 & Pori & 115 & Sisä-Savo & 176 & Nivala-Haapajärvi \\
\hline 044 & $\begin{array}{l}\text { Pohjois- } \\
\text { Satakunta }\end{array}$ & 122 & Joensuu & 177 & Ylivieska \\
\hline 051 & Hämeenlinna & 124 & Keski-Karjala & 178 & Koillismaa \\
\hline 052 & Riihimäki & 125 & Pielisen Karjala & 181 & Kehys-Kainuu \\
\hline 053 & Forssa & 131 & Jyväskylä & 182 & Kajaani \\
\hline 061 & $\begin{array}{l}\text { Luoteis- } \\
\text { Pirkanmaa }\end{array}$ & 132 & Joutsa & 191 & Rovaniemi \\
\hline 062 & $\begin{array}{l}\text { Kaakkois- } \\
\text { Pirkanmaa }\end{array}$ & 133 & Keuruu & 192 & Kemi-Tornio \\
\hline 063 & Etelä-Pirkanmaa & 134 & Jämsä & 193 & Torniolaakso \\
\hline 064 & Tampere & 135 & Äänekoski & 194 & Itä-Lappi \\
\hline 068 & $\begin{array}{l}\text { Lounais- } \\
\text { Pirkanmaa }\end{array}$ & 138 & $\begin{array}{l}\text { Saarijärvi- } \\
\text { Viitasaari }\end{array}$ & 196 & Tunturi-Lappi \\
\hline 069 & Ylä-Pirkanmaa & 141 & Suupohja & 197 & Pohjois-Lappi \\
\hline 071 & Lahti & 142 & Seinäjoki & 201 & Porvoo \\
\hline 072 & Heinola & 143 & $\begin{array}{l}\text { Eteläiset seinä- } \\
\text { naapurit }\end{array}$ & 202 & Loviisa \\
\hline 081 & Kouvola & 144 & Kuusiokunnat & 211 & Mariehamns stad \\
\hline 082 & Kotka-Hamina & 145 & Härmänmaa & 212 & Ålands landsbygd \\
\hline 091 & Lappeenranta & 146 & Järviseutu & 213 & Ålands skärgård \\
\hline 092 & Länsi-Saimaa & 151 & Kyrönmaa & & \\
\hline
\end{tabular}




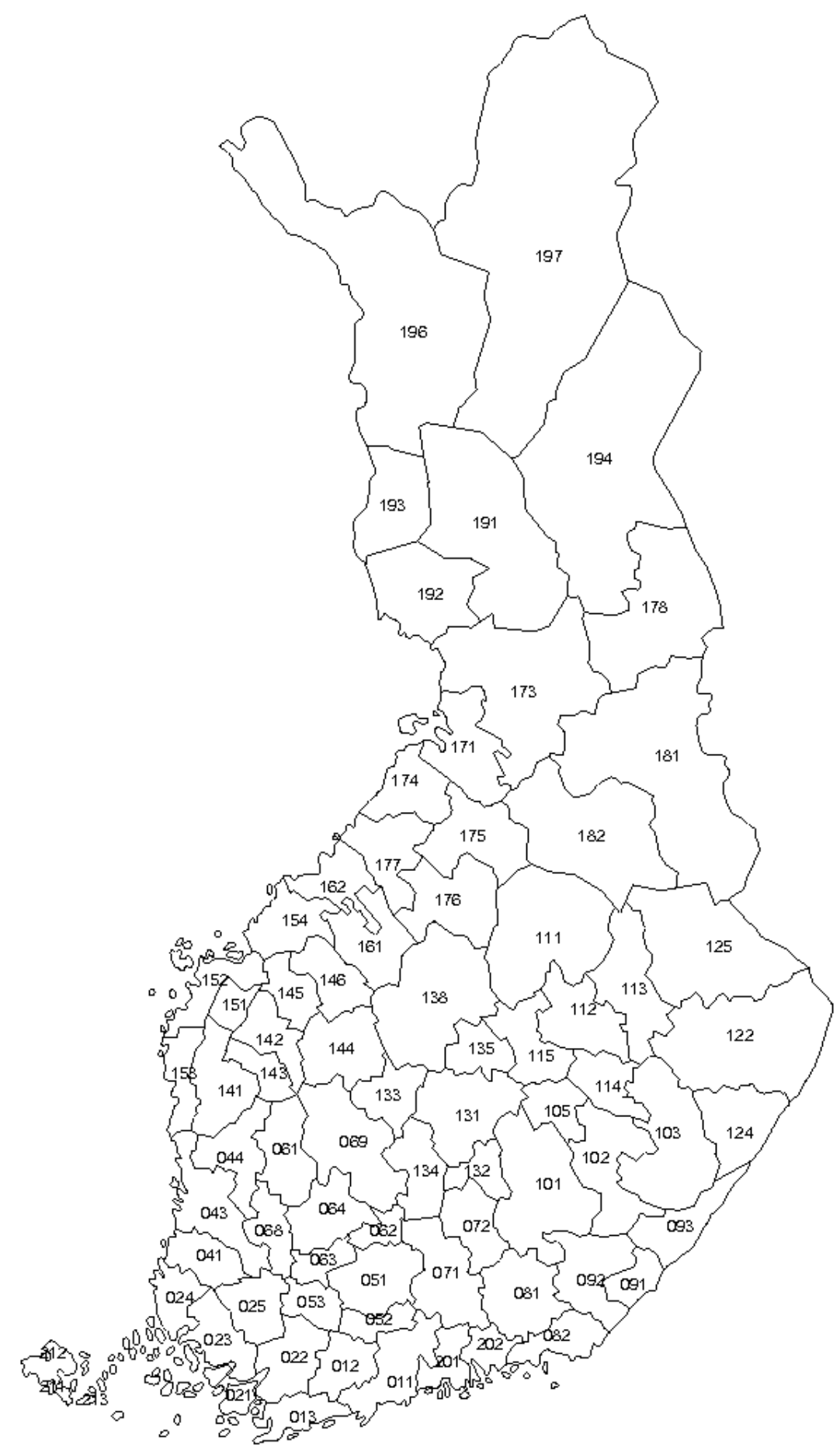

Figure 1: Map of Finnish sub-regional units in 2005. Source: Statistics Finland. 